\title{
ВЗАИМОДЕЙСТВИЕ ВОСПИТАТЕЛЯ С РОДИТЕЛЯМИ ПО РАЗВИТИЮ РЕЧИ ДЕТЕЙ МЛАДШЕГО ДОШКОЛЬНОГО ВОЗРАСТА
}

\section{INTERACTION OF THE EDUCATOR WITH PARENTS ON THE DEVELOPMENT OF SPEECH OF CHILDREN OF YOUNGER PRESCHOOL AGE}

\section{E. Ganich}

Summary: The role of the educator is to competently build work with parents aimed at the development of children's speech, to organize joint work of the educator with parents on the development of speech of children of younger preschool age, since it is the younger preschool age that is a unique period in the child's life, it is at this age that the child intensively masters speech.

Keywords: interaction, educator, parents, speech, children, younger preschool age.

\author{
Ганич Елена Викторовна \\ Аспирант, Академия последипломного образования \\ ganicelena27@gmail.com
}

Аннотация: Роль воспитателя заключается в том, чтобы грамотно построить работу с родителями, направленную на развитие речи детей, организовать совместную работу воспитателя с родителями по развитию речи детей младшего дошкольного возраста, так как именно младший дошкольный возраст является уникальным периодом в жизни ребенка, именно в данном возрасте ребенок интенсивно овладевает речью.

Ключевые слова: взаимодействие, воспитатель, родители, речь, дети, младший дошкольный возраст.
$\mathrm{P}$ ечь - явление социальное и служит средством общения людей друг с другом. Когда же начинается развитие детской речи? Многие родители считают, что в тот день, когда их малыш произнес первое слово, а на самом деле это происходит гораздо раньше. Этому дню предшествуют многие недели и месяцы, в течении которых ребенок учится отличать одни речевые звуки от других, а его артикуляционный аппарат приобретает гибкость и подвижность, которые необходимы для правильного и четкого произношения звуков и слов.

Маленький ребенок овладевает речью при непосредственном общении со взрослыми, подражая их речи. Что бы научиться говорить, ребенок должен прежде всего слышать речь. Формирование и развитие речи происходит постепенно. Если родители часто общаются со своим малышом, играют с ним, читают ему книги, учат с ним потешки и стихи, то как правило, речь ребенка развивается своевременно и правильно [1, с.17]. Естественно, своевременное и полноценное развитие речи детей младшего дошкольного возраста невозможно и без целенаправленной педагогической работы.

В последние годы наблюдается резкое снижение уровня речевого развития младших дошкольников. Одной из причин снижения уровня речевого развития является пассивность и неосведомленность родителей в вопросах данной области. Необходимым условием нормального развития речи является наличие благо- приятной языковой среды, чем больше ребенок общается с близкими людьми и родителями, тем интенсивнее и качественнее происходит его речевое развитие. В возрасте 3 - 4 лет ребенок как правило посещает младшую группу детского сада, но семья по-прежнему играет главную роль в воспитании ребенка, и от ее настроя зависит, насколько эффективным будет педагогическое воздействие дошкольного образовательного учреждения на речевое развитие ребенка.

В период от 3 до 4 лет, когда очевидными становятся недостатки речевого развития ребенка, идет интенсивная работа над качеством речи, без согласованных действий воспитателя и родителейдобиться положительных результатов очень сложно. Здесь очевидна обоюдная заинтересованность. Именно в этот период начинается активное взаимодействие воспитателя и родителей в развитии речи детей младшего дошкольного возраста. Взаимодействие представляет собой способ организации совместной деятельности, которая осуществляется на основании социальной перцепции и с помощью общения [2, с.32]. Личное взаимодействие воспитателя с родителями, методы и формы работы с родителями, просвещение родителей с целью повышения уровня их педагогического образования несомненно приведут к блестящему результату в речевом развитии детей младшего дошкольного возраста.

На начальном этапе работы с родителями, воспита- 
тель может рекомендовать родителям соблюдать ряд условий:

- не стараться ускорить ход естественного речевого развития ребенка;

- в общении с ребенком следить за своей речью;

- не подделывать под детскую свою речь;

- своевременно устранять недостатки речи ребенка;

— не оставлять без ответа вопросы ребенка.

На одном из первых мест в работе воспитателя должна стоять работа, направленная на взаимодействие его с родителями, позволяющая повысить осведомленность родителей в вопросах речевого развития детей, подвести к осознанию важности вклада в речевое развитие их ребенка и привлечь их к совместной работе с целью повышения эффективности речевого развития своего ребенка. Только четко выстроенная, хорошо организованная работа, в каком бы направлении она не велась, (а в данном случае это взаимодействие воспитателя с родителями) может дать положительные результаты.

Задача воспитателя - вооружать родителей педагогическими знаниями, в частности конкретными знаниями по методике развития речи. Для этого можно использовать различные формы работы. На групповых собраниях родителей в начале года педагог знакомит их с новыми задачами воспитания, рассказывает, какие речевые навыки наиболее существенны на данной возрастной ступени, знакомит с основными ошибками в речи детей. Важно, чтобы воспитатель заострил внимание на задачах развития речи, стоящих перед детским садом, на том, какую помощь в развитии речи ребенка может оказать семья.

Интересными и полезными для молодых родителей являются собрания, на которых выступают и делятся своими впечатлениями о развитии речи в условиях семьи сами родители [4, с.20]. Можно использовать такие формы, как тематические лекции, беседы и консультации специалистов по проблемам речи. В беседах и консультациях воспитатель знакомит родителей с во- просами речевого развития детей. Полезно ознакомить родителей с процессом формирования речи детей младшего дошкольного возраста.

Эффективны организации стендов, где вывешиваются небольшие заметки, статьи по развитию речи детей младшего дошкольного возраста. Необходимо составить подробный список литературы для родителей, подготовить советы, которые помогут им организовать работу по расширению кругозора ребенка, усвоению основных правил речи. В родительском уголке можно систематически помещать краткие советы по развитию речи детей, небольшие тексты (загадки, пословицы, отрывки из стихотворений), которые родители могут использовать, разговаривая с ребенком.

Досуговые формы организации общения воспитателя с родителями помогают устанавливать тёплые неформальные отношения между воспитателем и родителями, а также доверительные отношения между родителями и детьми, способствуют повышению педагогической культуры родителей и обогащению словаря детей [5, с.12]. Досуговые формы сотрудничества с родителями могут быть эффективными тогда, когда воспитатели уделяют достаточное внимание педагогическому содержанию мероприятия. Родители на данных мероприятиях могут читать стихотворения вместе со своим ребенком, петь песни и рассказывать интересные истории.

Родители могут стать активными участниками жизни детей при посещении группы. Они могут сами поучаствовать в играх, занятиях и т.д. Данная педагогическая разработка плавно включает родителей в образовательный процесс как равноправных участников.

Степень эффективности взаимодействия должна быть обусловлена положительной установкой взаимодействующих сторон на совместную работу по развитию речи детей, осознанием её целей и личностной заинтересованности. Взаимодействие воспитателя с родителями - необходимое условие полноценного речевого развития детей младшего дошкольного возраста.

\section{ЛИТЕРАТУРА}

1. Афонькина Ю.А. Организация деятельности Центра игровой поддержки ребенка раннего возраста: конспекты игровых дней / Ю. А. Афонькина, Е.М. Омельченко. - Волгоград: Учитель, 2012. - 205 с.

2. Гербова В.В. Развитие речи в разновозрастной группе детского сада. Младшая разновозрастная группа. - М.: Мозаика-Синтез, 2009. - 128 с.

3. Затулина Г.Я. Конспекты занятий по развитию речи. Первая младшая группа. Учебное пособие. - М., Центр педагогического образования, 2008. - 160с.

4. Максаков А.И. Развитие правильной речи ребенка в семье. Пособие для родителей и воспитателей. 2-е изд. - М.: Мозаика-Синтез, 2008. - 112 с.

5. Родительские собрания в ДОу. Младшая и средняя группы. / Автор-сост. Т. В. Иванова. - Волгоград: ИТД "Корифей". - 96 с.

(c) Ганич Елена Викторовна (ganicelena27@gmail.com). 